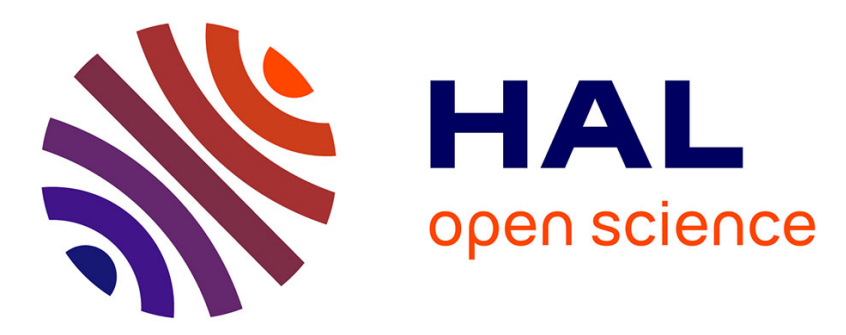

\title{
Influence of annealing conditions on the formation of hollow Al2O3 microspheres studied by in situ ESEM
}

F. Pedraza, R. Podor

\section{To cite this version:}

F. Pedraza, R. Podor. Influence of annealing conditions on the formation of hollow $\mathrm{Al} 2 \mathrm{O} 3$ microspheres studied by in situ ESEM. Materials Characterization, 2016, 113, pp.198-206. 10.1016/j.matchar.2016.01.018 . hal-02488953

\section{HAL Id: hal-02488953 \\ https://hal.science/hal-02488953}

Submitted on 24 Feb 2020

HAL is a multi-disciplinary open access archive for the deposit and dissemination of scientific research documents, whether they are published or not. The documents may come from teaching and research institutions in France or abroad, or from public or private research centers.
L'archive ouverte pluridisciplinaire HAL, est destinée au dépôt et à la diffusion de documents scientifiques de niveau recherche, publiés ou non, émanant des établissements d'enseignement et de recherche français ou étrangers, des laboratoires publics ou privés. 


\section{INFLUENCE OF ANNEALING CONDITIONS ON THE FORMATION OF HOLLOW $\mathrm{Al}_{2} \mathrm{O}_{3}$ MICROSPHERES STUDIED BY IN SITU ESEM}

F. Pedraza ${ }^{1 *}$ and R. Podor ${ }^{2}$

${ }^{1}$ LaSIE. Université de La Rochelle UMR-7356-CNRS. Pôle Sciences et Technologie. Avenue Michel Crépeau. 17042 La Rochelle cedex 1. FRANCE.

${ }^{*}$ Corresponding author:

e-mail: fpedraza@univ-Ir.fr

Telephone: +33546458297

${ }^{2}$ Institut de Chimie Séparative de Marcoule, UMR 5257 CEA-CNRS-UM2-ENSCM Site de Marcoule. BP 17171 -30207 Bagnols sur Cèze cedex. FRANCE.

e-mail : renaud.podor@cea.fr

Telephone : +33466339202

\section{Abstract}

The transformation of $\mathrm{Al}$ microparticles into hollow and broken $\mathrm{Al}_{2} \mathrm{O}_{3}$ microspheres was investigated by in situ environmental scanning electron microscopy (ESEM) up to $1150^{\circ} \mathrm{C}$ under different heating rates and $120 \mathrm{~Pa}$ of gas atmospheres. Slow heating rates $\left(2^{\circ} \mathrm{C} \mathrm{min}-1\right)$ resulted in a better coverage of the particles shell than with fast heating rates $\left(20^{\circ} \mathrm{C} \mathrm{min}{ }^{-1}\right)$ that delayed the threshold temperature at which the particles opened. Above this threshold, the amount of opened spheres increased with heating rate, with the coarser particles opening more than the small ones. It appeared that inert atmospheres $\left(\mathrm{He}-4 \% \mathrm{H}_{2}\right)$ increased the temperature at which the particles transformed, while air and pure oxygen tended to lower it. In contrast, the temperature interval was larger and was size-dependent when using water vapour. Irrespective of the gas atmosphere, opening of the spheres allowed molten Al to flow 
out from the core and aluminise the substrate while leaving behind a top coat of hollow alumina spheres.

Keywords: aluminium microparticles; annealing; oxidation; coating; electron microscopy

\section{1.- Introduction}

The synthesis methods and mechanisms involved in the transformation of bulk into hollow and capsule (broken) oxide nanoparticles have received considerable attention over the past few years because of the great variety of applications [1]. Whereas some review works focused on the fabrication methods of such hollow nanoparticles [1,2] other papers highlighted that the major mechanisms of formation are related to Kirkendall interdiffusion for instance in $\mathrm{Ni} / \mathrm{NiO}$ [3] or in $\mathrm{Cu} / \mathrm{Cu}_{2} \mathrm{O}[4,5]$ to Cabrera-Mott mechanism, in which the electrostatic fields outweigh Kirkendall interdiffusion in the initial oxidation stages of $\mathrm{Al} / \mathrm{Al}_{2} \mathrm{O}_{3}$ systems $[4,5]$ and to Ostwaldripening in template-free $\mathrm{Sn} / \mathrm{SnO}_{2}[6]$ or $\mathrm{Ti} / \mathrm{TiO}_{2}[7]$ to describe the preferential dissolution of the particle interior because of thermodynamic or energetic considerations.

The synthesis of nano $\mathrm{Al} /$ porous $\mathrm{Al}_{2} \mathrm{O}_{3}$ by template or wet chemical methods requires a final calcination step at high temperature in oxygen-rich atmospheres $[8,9]$. This results in the formation of hollow particles of alumina by enhanced diffusion of oxygen through the oxide shell [10]. The strong energy release upon the exothermic combustion reactions is also the basis of explosives [11] and therefore, various works have been devoted to ascertain the oxidation mechanisms of aluminium powders where the particle size, the heating rate and the annealing atmosphere have been considered [10,12-16]. Different major phenomena are agreed to occur below, at and over the Al melting temperature $\left(660^{\circ} \mathrm{C}\right)$ whereby the amorphous alumina shell surrounding the $\mathrm{Al}$ metallic core grows $\left(300-550^{\circ} \mathrm{C}\right)$ and converts into a $\gamma-\mathrm{Al}_{2} \mathrm{O}_{3}$ oxide layer (from $550^{\circ} \mathrm{C}$ and above) that eventually transforms into $\theta$ or $\alpha-\mathrm{Al}_{2} \mathrm{O}_{3}$ at much higher temperatures (above $900^{\circ} \mathrm{C}$ ) [12]. In air, Trunov et al. demonstrated that the small particles 
ignite faster and at lower temperature than the coarse ones while the oxidation steps are shifted towards higher temperatures with increasing the heating rates [12]. In inert atmospheres, Rufino et al. reported that crystallization of the alumina layer surrounding the Al metallic core occurs before the melting of Al regardless of the particle size $(157 \mathrm{~nm}$, and 1.2 or $17 \mu \mathrm{m}$-mean diameter-) [13]. However, under oxidizing conditions, ignition was also dependant on particle size even though the thickness of the alumina shell was similar [12]. In addition, the particles coalesced under oxidative conditions but not in inert atmospheres thereby demonstrating the influence of the annealing atmosphere [13]. Broken-up (crater-like) and cracked particles were explained to occur due to the receding molten Al interface as the metal flowed out of the particles through cracks and pores [13]. However, the conditions at which such morphologies appear are much related to the thickness of the crystallized alumina shell as the oxide may become mechanically stable and thus, cannot follow the thermal expansion of the aluminium core [15]. Such increase of the oxide thickness has been shown to be strongly dependant on the annealing atmosphere by tracking the oxidation kinetics as a function of heating rate and particle size in $\mathrm{Ar}, \mathrm{O}_{2}, \mathrm{H}_{2} \mathrm{O}$ and $\mathrm{CO}_{2}$ (and combinations thereof) $[14,16]$. It clearly appears that water greatly influences the oxidation kinetics compared to oxygen and carbon dioxide but the stepwise oxidation rate changes are better defined for coarse $(10-14 \mu \mathrm{m})$ than for small $(4.5-7$ and 3-4.5 $\mu \mathrm{m})$ particles and for low heating rates (2 and $5^{\circ} \mathrm{C} \mathrm{min}-1$ compared to 10 and $\left.20^{\circ} \mathrm{C} \mathrm{min}^{-1}\right)[14,16]$. The influence of particle size is also clearly demonstrated when comparing the works of Hasani et al. for 100-200 $\mu$ m particles [1719] and of Velasco et al. for $3.5 \mu \mathrm{m}$ particles [20] oxidized in air under both isothermal and non-isothermal conditions. The small particles formed hollow particles after their complete oxidation whereas the coarse ones were not completely oxidized even after exposures to $1400^{\circ} \mathrm{C}$

However, the mechanisms of formation of the hollow/broken alumina particles have been discussed for self-standing particles either in the nano or sub-micron range for combustion 
applications (explosives) or in the micro-scale from post-mortem observations after cooling and not for thermal barrier coating applications where the hollow and broken alumina microparticles were shown to thermally shield the nickel-based substrate [21]. Indeed, preliminary investigations where a slurry containing a different range of $\mathrm{Al}$ microparticles deposited onto pure metals or alloys followed by different heat treatments allowed to form a top coat of hollow alumina spheres, and an aluminium-diffused layer underneath both linked through an $\mathrm{Al}_{2} \mathrm{O}_{3}$ based thermally grown oxide [22-24].

In contrast to previous works, this paper therefore investigates the mechanisms of formation of the hollow alumina top coat from microsized particles ( $5 \mu \mathrm{m}$ of mean diameter) at different heating rates and annealing atmospheres by in situ environmental scanning electron microscopy (ESEM) at high temperature. Correlations with post-mortem SEM after cooling of the specimens are also established to elucidate the formation of the top coat of hollow and broken alumina spheres.

\section{2.- Materials and Methods}

A slurry containing $50 \mathrm{wt} \%$ of $99.7 \%$ pure Al-microparticles with a narrow distribution around 5 $\mu \mathrm{m}(\mathrm{D} 10=3.57 \mu \mathrm{m}, \mathrm{D} 50=5.42 \mu \mathrm{m}, \mathrm{D} 90=8.24 \mu \mathrm{m})$ produced by the wire explosion method [25] by Sibthermochim (Russia) and 50 wt\% of $1 / 10$ polyvynil alcohol (PVA)/milliQ water binder was prepared at room temperature [26] and air-sprayed onto a nickel based superalloy substrate (Ni-13.8Cr-9Co-0.6Mo-1.2W-1.6Ta-7.8Al-5Ti, at\%) kindly supplied by Siemens. The air/slurry ratio was greater (2) than the one typically employed to produce even slurry coatings (1.4) [24] in such a manner that open pores can be obtained in the coating to observe the coating/substrate interactions upon heating. The in situ observations were made in a FEI Quanta 200 environmental scanning electron microscope (ESEM) FEG microscope. A dedicated furnace equipped with a platinum heating element allows heating $6 \mathrm{~mm}$ diameter pieces directly in the ESEM chamber up to $1400^{\circ} \mathrm{C}$, under maximum $750 \mathrm{~Pa}$ 
atmosphere. The sample temperature is controlled by a homemade $\mathrm{Pt}-\mathrm{Pt} / \mathrm{Rh} 10$ thermocouple placed in the sample holder below the sample to be studied [27] with a $\pm 5^{\circ} \mathrm{C}$ accuracy at the gold melting point $\left(1064^{\circ} \mathrm{C}\right)$. In the present case the samples were square-like $\left(3 \times 3 \mathrm{~mm}^{2}\right)$ and $1.2 \pm 0.1 \mathrm{~mm}$ thick. Heating rates of $2,5,10$, and $20 \mathrm{C} \mathrm{min}^{-1}$ were employed in $120 \mathrm{~Pa}$ of different gas atmospheres $\left(\mathrm{He}-4 \% \mathrm{H}_{2}, \mathrm{O}_{2}\right.$, air and $\left.\mathrm{H}_{2} \mathrm{O}\right)$ up to $1150^{\circ} \mathrm{C}$. high purity $\mathrm{He}-4 \% \mathrm{H}_{2}(\mathrm{~g})$ and $\mathrm{O}_{2}$ (g) from Alphagaz were injected from a gas bottle into the SEM chamber. Air came from the SEM room and contained less than $1 \mathrm{~Pa}$ of water vapour in $120 \mathrm{~Pa}$ of air. $\mathrm{H}_{2} \mathrm{O}$ was generated by heating a milliQ water reservoir and the vapour was injected into the SEM chamber through a Baratron pressure gauge to control a stable pressure of $120 \mathrm{~Pa}$. The main advantage of the use of the HT-ESEM is to record image series of the sample surface with a nanometre resolution upon annealing $[28,29]$. Image analyses to evaluate the number and the average radius of particles evolving with temperature under different testing conditions were performed in a $100 \times 125 \mu \mathrm{m}^{2}$ area using ImageJ software [30]. Post-mortem SEM/EDS analyses were also carried out in a FEI Quanta 200F with an EDAX detector in environmental mode to avoid charging effects of insulating materials.

\section{3.- Results}

\section{1.- Influence of heating rate:}

Heating in $\mathrm{He}-4 \% \mathrm{H}_{2}$ (inert) gas at different rates (from 2 to $20^{\circ} \mathrm{C} \mathrm{min}{ }^{-1}$ ) did not result in any transformation of the particles until $690-700^{\circ} \mathrm{C}$ (Figure 1). In this temperature interval, the spheres began to break. Using image analysis, the amount of opened spheres was determined to increase with the heating rate (Table 1). Furthermore, the mean diameter of the opened spheres was greater $(7.00 \pm 0.50 \mu \mathrm{m})$ than that $(3.75 \pm 0.25 \mu \mathrm{m})$ of the non-opened spheres (at 2 and $\left.10^{\circ} \mathrm{C} \mathrm{min}^{-1}\right)$. These effects of heating rate and particle size appeared to be strongly dependent on the transformations of the $\mathrm{Al}_{2} \mathrm{O}_{3}$ oxides morphology. Indeed, the slow growth of a compact $\mathrm{Al}_{2} \mathrm{O}_{3}$ shell was observed at low heating rates compared to the more porous shells grown at faster rates through which molten Al flowed out from the core. Similarly, the surface 
of the small particles appeared better covered with oxide than the coarse ones and opened more easily.

\section{2.- Influence of gas atmosphere (inert, water vapour, oxygen and air)}

The comparison of $\mathrm{He}-4 \% \mathrm{H}_{2}, \mathrm{H}_{2} \mathrm{O}, \mathrm{O}_{2}$ or air in the chamber with a fast heating rate $\left(20^{\circ} \mathrm{C} \mathrm{min}-1\right)$ up to about $750^{\circ} \mathrm{C}$ highlighted interesting differences. The pictures at the left of Figure 2 are taken at $665^{\circ} \mathrm{C}$ whereas the ones shown at the right indicate the temperature at which the particles began to open. The complete videos are reported on supplementary files S1 to S4. In inert atmosphere, most the particles bursted suddenly at $695^{\circ} \mathrm{C}$. In contrast, water vapour allowed to break the spheres progressively at a higher and larger temperature interval $\left[668,720^{\circ} \mathrm{C}\right]$ than in oxygen $\left[665,670^{\circ} \mathrm{C}\right]$. In air, the temperature interval for the spheres to break was similar than in water vapour.

\section{3.- Post-mortem observations}

Figure 3 shows the overall view of the surface exposed to $120 \mathrm{~Pa}$ of inert, oxygen and water vapour atmosphere after cooling from $1150^{\circ} \mathrm{C}$. The particles looked all well sintered but were more deformed and broken (open) in the inert gas than in oxygen or water vapour and had some bright contrasted areas that were found to be rich in nickel. Within the pores, molten Al was seen to come out from the spheres to aluminize the substrate (Figure 4a). In tilt mode $\left(30^{\circ}\right)$ (Figure 4b), a layered structure with a "cliff" appearance developed underneath the hollow particles with two clearly distinctive areas. The top one contained numerous layers whereas the bottom one was more even in morphology and composition according to the backscattered electron contrast. The spot EDS analyses on such different areas (Figure 4c) suggested that the surface of the substrate was oxidised even in the inert atmosphere with major contributions from Al, Cr and Ti. Moving upwards from the substrate to the top coat of spheres, the oxygen and Al contents increased whereas those of the alloying elements of the substrate decreased $(\mathrm{Cr}, \mathrm{Ti}$ and $\mathrm{Co})$. The enrichment of $\mathrm{Ni}$ in the bottom area of the "cliff" is a clear indication that 
nickel dissolved into molten Al at relatively low temperatures [31-33] and therefore the surface of the substrate was poorer in nickel than in the bulk alloy. The interdiffusion of $\mathrm{Al}$ and $\mathrm{Ni}$ resulted in the aluminisation of the substrate (Figure $4 d$ ).

\section{4.- Discussion}

\section{1.- Mechanism of formation of individual $\mathrm{Al}_{2} \mathrm{O}_{3}$ hollow spheres}

The transformation of $\mathrm{Al}$ into hollow and broken $\mathrm{Al}_{2} \mathrm{O}_{3}$ particles considers two concomitant mechanisms including the oxidation of the $\mathrm{Al}$ shell and the melting and release of $\mathrm{Al}$ at temperatures at or above the melting temperature of $\mathrm{Al}\left(660^{\circ} \mathrm{C}\right)$. The latter is known to be influenced by the presence of impurities that form eutectic (molten) phases at lower temperatures [34]. Here, we also demonstrate that the release of Al from the spheres and the simultaneous oxidation are shown to be strongly dependent on heating rate and gas species in the chamber, in agreement with other reports $[12,13,14,16]$. Indeed, the agreed mechanisms of the very initial formation of hollow and broken particles are based on the Cabrera-Mott mechanism whereby the electric fields make $\mathrm{Al}$ and $\mathrm{O}$ to diffuse at different rates in the very initial oxidation steps [4] after which the Kirkendall difference of metal and oxygen flow take the lead at least below the melting temperature of $\mathrm{Al}\left(660^{\circ} \mathrm{C}\right)$ [35]. Aluminium being hydroxylated in the slurry, the shell of the oxo-hydroxide grows with temperature until the binder is burned or evaporated [26] and is subsequently transformed into the $\gamma-\mathrm{Al}_{2} \mathrm{O}_{3}$ at about $550^{\circ} \mathrm{C}$ in air [12] then in $\theta$ - and $\alpha-\mathrm{Al}_{2} \mathrm{O}_{3}$ at higher temperatures [11,12] but direct transformation $\gamma$ into $\alpha-\mathrm{Al}_{2} \mathrm{O}_{3}$ can also occur [36]. These phase transformations bring about shrinkage of the shell [13] and therefore open access to molten Al to flow outside of the spheres [24] and/or to be injected into the shell [37] and expand [38]. The disruption of the oxide film depends mostly in the differences in the thermal expansion coefficients and densities of the metal and its oxide, as well as in the volume change of the metal during phase or polymorphic transformations [39]. However, when the thickness of the oxide shell is sufficiently thick and thus, mechanically stable, compressive strains in the Al core and tensile stresses in the oxide shell appear 
irrespective of the particle size [13]. Mechanically damaging of the oxide shell was quoted to reduce the melting temperature due to a decrease in generated pressure within the Al core in nanoparticles [40]. However, no breakage of the shell was required until complete melting of the core for very fast heating rates. Trunov et al. found that the increase of the heating rate shifted the oxidation steps towards higher temperatures in air and related this phenomenon to additional heat release due to oxidation over heat capacity of the microparticles [12]. However, the oxidation effect cannot solely explain this phenomenon as our experiments in both inert $\left(\mathrm{He}-4 \% \mathrm{H}_{2}\right)$ and $\mathrm{O}_{2}$ atmospheres resulted both in the full opening of the spheres below $700^{\circ} \mathrm{C}$ even though our tests were carried out at low pressure $(<750 \mathrm{MPa})$ instead of atmospheric pressure like in [12]. It rather appears that the fast heating rates do not allow the Al core to sufficiently heat up. Therefore, the Al core cannot expand and create a pressure build-up within the particles to make them burst over the theoretical melting temperature of Al. This hypothesis would be in agreement with the findings of Hasani et al. on their tension analysis during oxidation of pure Al particles [18], who reported that the higher stresses imposed on the crust by the melt resulted in more intense oxidation after rupture, hence in the bursting of the particles that we observed in this work.

In contrast, it appears that the critical point corresponding to the particle opening is clearly dependent on time and temperature for a given annealing atmosphere and heating rate as also demonstrated by Velasco et al. on 3.7 microsized Al particles [20]. An example of image series is reported on Figure 5 for a $120 \mathrm{~Pa} \mathrm{He}+4 \% \mathrm{H}_{2}$ atmosphere where the evolution from full to hollow particles is shown (see supplementary file S5 for complete video). Before the opening, the particles deform progressively. Above a deformation threshold, the liquid Al trapped in the particle flows outside and the particle is emptied. This final modification occurs very rapidly (the delay between two images is 4 seconds) and leaves behind the alumina shell. The opening of the alumina shell always appears in the areas that were largely deformed. However, liquid $\mathrm{Al}$ is not directly observed on the surface since it was shown to flow towards 
the underlying substrate and between the Al particles [32]. The thickness of the oxide shell appears to be very thin under $\mathrm{He}+4 \mathrm{H}_{2}$ and $\mathrm{O}_{2}$. This is in good agreement with data reported by Rufino et al. who determined 15 to $30 \mathrm{~nm}$-thick alumina layers when annealing aluminium particles in air up to $660^{\circ} \mathrm{C}[13]$.

\section{2.- General behaviour of a population of $\mathrm{Al}_{2} \mathrm{O}_{3}$ hollow spheres.}

Statistical results on the particle population were obtained by changing the gas composition in the chamber. Figure 6 displays the statistical distribution of the number of particles that opened in $\mathrm{He}-4 \% \mathrm{H}_{2}, \mathrm{O}_{2}$, air and $\mathrm{H}_{2} \mathrm{O}$. Air was introduced in this comparative study since flowing $\mathrm{N}_{2}(\mathrm{~g})$ could potentially nitride $\mathrm{Al}$ although the pressure required to produce nitridation is about five times greater than for oxidation [41]. It appears that the greatest number of particles breakage is centred at around $675^{\circ} \mathrm{C}$ for both $\mathrm{O}_{2}$ and air and thereby nitrogen does not affect the behaviour in this temperature range. A larger distribution centred between $680-690^{\circ} \mathrm{C}$ occurs with $\mathrm{H}_{2} \mathrm{O}$. In contrast, the inert atmosphere has two distribution areas, one centred at 690 and a second one at $705^{\circ} \mathrm{C}$.

These results seem to confirm that the opening of the spheres can be governed by various mechanisms implying (a) the burning of the organic binder covering the shells and (b) the transformation and the stabilisation of the $\gamma-\mathrm{Al}_{2} \mathrm{O}_{3}$ covering the shells. Indeed, in the inert atmosphere, the deshydroxylation of Al occurs at about $625^{\circ} \mathrm{C}$ because of the transformation of the boehmite type structure into the amorphous alumina [42]. However, in the presence of oxidising species the organic binder was observed to burn. Therefore, direct transformation of the hydroxide into the $\gamma-\mathrm{Al}_{2} \mathrm{O}_{3}$ oxide occurs [43]. This transformation can be also accompanied by shrinkage of the shell allowing Al outward diffusion that likely incorporates in the shell $[37,38]$ and, with temperature, is transported towards other particles and/or the substrate [21]. 
However, the extent at which this phenomenon occurs is size-dependent as shown in Figure 7, where the mean particle radius opening with respect temperature is plotted for different gas atmospheres. Indeed, the coarse particles break up at lower temperatures than the small ones regardless of the gas atmosphere. This can be attributed to the larger (re)active surface of the small particles thereby oxidising quicker but is in contrast with the results from Trunov et al., who claimed that the smaller Al microparticles ignited faster and at lower temperatures than the coarser ones in spite of the widely varying ignition temperatures [12]. Rufino et al. also reported that the nanopowders displayed a greater reactivity than the microparticles but the thickness of the alumina layer was independent of the particle size because the diffusion of oxygen was slowed down by the crystallized alumina [13]. Two major reasons can help in explaining these apparently, contradictory observations. First, the above studies referred to very different particle sizes (3-4.5 and 10-14 $\mu \mathrm{m}$ [12] and $200 \mathrm{~nm}, 1.60$ and $8.35 \mu \mathrm{m}$ [13]) whereas our particle distribution is much narrower $(\mathrm{D} 10=3.57 \mu \mathrm{m}, \mathrm{D} 50=5.42 \mu \mathrm{m}, \mathrm{D} 90=8.24$ $\mu \mathrm{m})$ and secondly, our particles were oxy-hydroxylated by the PVA/ $\mathrm{H}_{2} \mathrm{O}$ binder in the slurry prior to heating in the different atmospheres. The smallest particles $(5 \mu \mathrm{m})$ indeed underwent greater mass losses than the coarse ones $(20 \mu \mathrm{m})$ when annealed in TGA tests [26], which is indicative of enhanced adsorption of PVA to the small particles. In addition, whereas transformation of boehmite $(\mathrm{AlOOH})$ into $\gamma-\mathrm{Al}_{2} \mathrm{O}_{3}$ has been quoted to occur at $400^{\circ} \mathrm{C}$ in the absence of binder, the addition of PVA resulted in nano pore and crack-free $\gamma-\mathrm{Al}_{2} \mathrm{O}_{3}$ membranes [44] that makes alumina being stable till about $800^{\circ} \mathrm{C}$ [45]. Additional heating at higher temperatures indeed showed that grain growth, appearance of greater number of voids and of whisker formation only occurred from 975 and $1060^{\circ} \mathrm{C}$, respectively, in $\mathrm{H}_{2} \mathrm{O}$ and $\mathrm{O}_{2}$. Such evolution of the morphology can be associated with $\alpha-\mathrm{Al}_{2} \mathrm{O}_{3}$ [36] also observed on the studies of thermal barrier coating formation on pure nickel from a slurry containing Al microspheres [24]. 
Another interesting parameter to be determined is the ratio between the number of reacting particles versus the total number of particles. The images reported on Figure 8 illustrate the sample surface morphology at $850^{\circ} \mathrm{C}$, depending on the reacting atmosphere. The surface coverage rates are $33.5 \%, 73.6 \%$ and $79.2 \%$ in, respectively, $\mathrm{He}+4 \% \mathrm{H}_{2}, \mathrm{O}_{2}$ and $\mathrm{H}_{2} \mathrm{O}$, respectively (heating rate of $5^{\circ} \mathrm{C} \mathrm{min}^{-1}$ ). The reacting atmosphere has therefore a great influence on the ability of the Al particles to form hollow alumina spheres, oxygen and water vapour being the most favourable, which is in agreement with the studies of Schoenitz at al. [14] and Zhu et al. [16]. This can be related to enhanced growth of the $\mathrm{Al}_{2} \mathrm{O}_{3}$ layer in these oxidising conditions.

\section{3.- Aluminisation of the substrate}

The supply of Al from the spheres to the Ni-based substrate was also directly observed at a $5^{\circ} \mathrm{C} \mathrm{min}^{-1}$ of heating rate and was concomitant with the formation of the hollow spheres (Figure 9, see supplementary file S6 for complete video). As molten Al flows, dissolution of $\mathrm{Ni}$ occurs that provokes great exothermal reactions between $\mathrm{Al}$ and $\mathrm{Ni}$, with a subsequent local temperature increase that entertains a self-propagating combustion synthesis mechanism [33]. Therefore, as far as the $\mathrm{Al}$ reservoir is not exhausted, $\mathrm{Al}$ and $\mathrm{Ni}$ interdiffusion occurs along the heat treatment that results in the aluminisation of the substrate underneath the top coat of hollow spheres (Figure 4).

\section{5.- Summary and conclusions}

SEM in situ investigations at high temperature and different gas atmospheres and heating rates allowed to identify the mechanisms of formation of hollow alumina particles from $\mathrm{Al}$ microparticles. Whereas the fast heating rates resulted in the bursting of particles, more oxidising atmospheres allowed to thicken the oxide shell. The opening of the spheres was therefore shifted to higher temperatures. Opening or bursting of the particles allowed molten Al to flow towards the substrate and to simultaneously aluminise it. Such multi-layered system 
with hollow/broken spheres of alumina on top and a $\mathrm{Ni}_{x} \mathrm{Al}_{\mathrm{y}}$ aluminised layer underneath open then new ways of investigation for potential applications as thermal barrier coating systems due to the insulating character of entrapped air in the spheres.

\section{6.- Acknowledgements}

Part of this work was performed under the programme PARTICOAT FP7-NMP-2007-LARGE1-CP-IP-211329-2 (2008-2012) funded by the European Union.

\section{7.- REFERENCES}

[1] Lou XW, Archer LA, Yang Z. Hollow Micro-/Nanostructures: Synthesis and Applications. Adv Mater 2008; 20: 3987-4019

[2] Bertling J, Blömer J, Kümmel R. Hollow microspheres. Chem Eng Technol 2004; 27: 829837.

[3] Railsback JG, Johnston-Peck AC, J. Wang J, Tracy JB. Size-dependent nanoscale Kirkendall effect during the oxidation of nickel nanoparticles. ACS Nano 2010; 4: 19131920.

[4] Nakamura R, Lee JG, Tokozakura D, Mori H; Nakajima H. Formation of hollow ZnO through low-temperature oxidation of Zn nanoparticles. Mater Lett 2007; 61: 1060-1063.

[5] Nakamura R, Tokozakura D, Nakajima H, Lee JG, Mori H. Hollow oxide formation by oxidation of Al and Cu nanoparticles, J Appl Phys 2007; 101: 074303.

[6] Lou XW, Wang Y, Yuan C, Lee JY, Archer LA. Template-free synthesis of $\mathrm{SnO}_{2}$ hollow nanostructures with high lithium storage capacity. Adv Mater 2006; 18: 2325-2329.

[7] Li HX, Bian ZF, Zhu J, Zhang DQ, Li GS, Huo YN, Li H, Lu YF. Mesoporous titania spheres with tunable chamber structure and enhanced photocatalytic activity. J Am Chem Soc 2007; 129: 8406-8407. 
[8] Liu R, Li Y, Zhao H, Zhao F, Hu Y. Synthesis and characterization of $\mathrm{Al}_{2} \mathrm{O}_{3}$ hollow spheres. Mater Lett 2008; 62: 2593-2595.

[9] Guo XF, Kim YS, Kim GJ. Fabrication of $\mathrm{SiO}_{2}, \mathrm{Al}_{2} \mathrm{O}_{3}$, and $\mathrm{TiO}_{2}$ microcapsules with hollow core and mesoporous shell structure, J Phys Chem 2009: C113: 8313-8319.

[10]Rai A, Park K, Zhou L, Zachariah MR. Understanding the mechanism of aluminum nanoparticle oxidation. Comb Theory Model 2006; 10: 843-859.

[11]Eisenreich N, Fietzek $H$, Juez-Lorenzo M, Kolarik V, Koleczko A, Weiser V. On the mechanism of low temperature oxidation for aluminum particles down to the nano-scale. Propellants Explosives Pyrotechnics 2004; 29: 137-145.

[12] Trunov MA, Schoenitz M, Zhu X; Dreizin EL. Effect of polymorphic phase transformations in $\mathrm{Al}_{2} \mathrm{O}_{3}$ film on oxidation kinetics of aluminum powders. Comb Flame 2005; 140: 310-318.

[13]Rufino B, Boulc'h F, Coulet MV, Lacroix G, Denoyel R. Influence of particles size on thermal properties of aluminium powder. Acta Mater 2007; 55: 2815-2827.

[14] Schoenitz M, Chen CM, Dreizin EL. Oxidation of aluminium particles in the presence of water. J Phys Chem 2009; B113: 5136-5140.

[15]Rufino B, Coulet MV, Bouchet R, Isnard O, Denoyel R. Structural changes and thermal properties of aluminium micro- and nano-powders. Acta Mater 2010; 58: 4224-4232.

[16]Zhu X, Schoenitz M, Dreizin EL. Oxidation of aluminum particles in mixed $\mathrm{CO}_{2} / \mathrm{H}_{2} \mathrm{O}$ atmospheres. J Phys Chem 2010; C114: 18925-18930.

[17] Hasani S, Panjepour M, Shamanian M. The oxidation mechanism of pure aluminium powder particles. Oxid Met 2012; 78: 179-195.

[18]Hasani S, Soleymani AP, Panjepour M, Ghaei M. A tension analysis during oxidation of pure aluminium powder particles: non isothermal condition. Oxid Met 2014; 82: 209-224.

[19]Hasani S, Panjepour M, Shamanian M. Non-isothermal kinetic analysis of oxidation of pure aluminium powder particles. Oxid Met 2014; 81: 299-313.

[20] Velasco F, S. Guzman S, Moral C, Bautista A. Oxidation of micro-sized aluminium particles: hollow alumina spheres. Oxid Met 2013; 80: 403-422. 
[21] Montero X, Galetz M, Schütze M, Mollard M, Rannou B, Bouchaud B, Bonnet G, Balmain J, Pedraza F. Multipurpose TBC system based in alumina foam top coat and Al-rich diffusion layer produced by micro-scaled Al slurries. 8th International Symposium on High Temperature Corrosion and Protection of Materials (HTCPM-2012), Les Embiez, France, May 2012.

[22] Kolarik V, Juez-Lorenzo M, Anchústegui M, Fietzek H. Multifunction high temperature coating system based on aluminium particle technology. Mater Sci Forum 2008; 595-598: 769-777.

[23] Montero X, Galetz M, Schütze M. A single step process to form in-situ an alumina foam/aluminide TBC system for alloys in extreme environments at high temperatures. Surf Coat Technol 2011; 206: 1586-1594.

[24]Pedraza F, Mollard M, Rannou B, Balmain J, Bouchaud B, Bonnet G. Potential thermal barrier coating systems from Al microparticles. Mechanisms of coating formation on pure nickel. Mater Chem Phys 2012; 134: 700-705.

[25]Ivanov YF, Osmonoliev MN, Sedoi S, Arkhipov VA, Bondarchuk SS, Vorozhstov AB, Korotkikh AG, Kuznetsov VT. Productions of ultra-fine powders and their use in high energetic compositions. Propell Explos Pyrot 2003; 28: 310-333.

[26]Rannou B, Velasco F, Guzmán S, Kolarik V, Pedraza F. Aging and thermal behaviour of a PVA/AI microspheres slurry for aluminizing purposes. Mater Chem Phys 2012; 134: 360365.

[27]Podor R, Pailhon D, Ravaux J, Brau HP. Development of an integrated thermocouple for the accurate sample temperature measurement during high temperature Environmental Scanning Electron Microscope (HT-ESEM) experiments. Microsc Microanal 2015; 21: $307-$ 312.

[28]Podor R, Clavier N, Ravaux J, Claparède L, Dacheux N. In situ HT-ESEM observation of $\mathrm{CeO}_{2}$ grain growth during sintering. J Am Ceram Soc 2012; 95: 3683-3690. 
[29]Boucetta H, Podor R, Schuller S, Stievano L, Ravaux J, Carrier X, Casale S, Gossé S Monteiro A. Mechanism of $\mathrm{RuO}_{2}$ crystallization in borosilicate glass: an original in situ ESEM approach. Inorg Chem 2012; 51: 3478-3489.

[30] Schneider CA, Rasband WS, Eliceiri KW. NIH Image to ImageJ: 25 years of image analysis. Nature Methods 2012; 9: 671-675.

[31]Rannou B, Mollard M, Bouchaud B, Balmain J, Bonnet G, Kolarik V, Pedraza F. On the influence of a heat treatment for an aluminizing process based on Al microparticles slurry for Ni and Ni20Cr. Experimental and theoretical approaches. Defect Diff Forum 2012; 323325: $373-379$.

[32] Bonnet G, Mollard, Rannou B, Balmain J, Pedraza F, Montero X, Galetz M, Schütze M. Initial aluminizing steps of pure nickel from Al micro-particles. Defect Diff Forum 2012; 323325: $381-386$.

[33] Galetz MC, Montero X, Mollard M, Günthner M, Pedraza F, Schütze M. The role of combustion synthesis in the formation of slurry aluminization. Intermetallics 2014 ; 44: 817.

[34]ASM-Binary alloy phase diagrams (1996). Metals Park (OH): ASM International.

[35]Park K, Lee D, Rai A, Mukherjee D, Zachariah MR. Size resolved kinetics measurements of aluminum nanoparticle oxidation by single particle mass spectrometry. J Phys Chem 2005; B109: 7290-7299.

[36]Levin I, Brandon D. Metastable alumina polymorphs: crystal structures and transition sequences. J Am Ceram Soc 1998; 81: 1995-2012.

[37]Rai A, Lee D, Park K, Zachariah MR. Importance of phase change of aluminum in the oxidation of aluminum nanoparticles. J Phys Chem 2004; B108: 14793-14795.

[38]Firmansyah DA, Sullivan K, Lee KS, Kim YH, Zahaf R, Zachariah MR, Lee D. Microstructural behaviors of alumina shell and aluminum core before and after melting of aluminum nanoparticles. J Phys Chem 2012; C116: 404-411. 
[39]Rosenband V. Thermo-mechanical aspects of the heterogeneous ignition of metals. Comb Flame 2004; 137: 366-375.

[40]Levitas VI, Pantoya ML, Chauhan G, Rivero I. Effect of the alumina shell on the melting temperature depression for aluminum nanoparticles. J Phys Chem 2009; C113: 1408814096.

[41]Okada T, Toriyama M, Kanzaki S. Direct nitridation of aluminum compacts at low temperature. J Mater Sci 2000; 35: 3105-3111.

[42] Yang WP, Shyu SS, Lee ES, Chao AC. Effects of PVA content and calcination temperature on the properties of PVA/boehmite composite film. Mater Chem Phys 1996; 45: 108-113.

[43] Kou $\mathrm{H}$, Wan J, Pan Y, Guo J. Hollow $\mathrm{Al}_{2} \mathrm{O}_{3}$ microspheres derived from $\mathrm{Al} / \mathrm{AlOOH} \cdot \mathrm{nH}_{2} \mathrm{O}$ core-shell particles. J Am Ceram Soc 2005; 88: 1615-1618.

[44]Lambert CK, Gonzalez RD. Effect of binder addition on the properties of unsupported $\gamma$ $\mathrm{Al}_{2} \mathrm{O}_{3}$ membranes. Mater Lett 1999; 38: 145-149.

[45]Lin YS, de Vries KJ, Burggraaf AJ. Thermal stability and its improvement of the alumina membrane top-layers prepared by sol-gel methods, J Mater Sci 1991; 26: 715-720. 
Table 1. Evolution of the quantity of reacted Al microparticles as a function of the heating rate in $120 \mathrm{~Pa} \mathrm{He}-4 \% \mathrm{H}_{2}$ annealing atmosphere (calculation made from images recorded at $\left.700^{\circ} \mathrm{C}\right)$.

\begin{tabular}{|l|r|c|}
\hline & $\begin{array}{l}\text { Opened particle } \\
\text { number (\%) }\end{array}$ & $\begin{array}{l}\text { Sample surface covered by } \\
\text { opened particles (\%) }\end{array}$ \\
\hline $2^{\circ} \mathrm{C} / \mathrm{min}$ & 27 & 33 \\
\hline $10^{\circ} \mathrm{C} / \mathrm{min}$ & 53 & 77 \\
\hline $20^{\circ} \mathrm{C} / \mathrm{min}$ & 100 & 100 \\
\hline
\end{tabular}




\section{List of Figure captions}

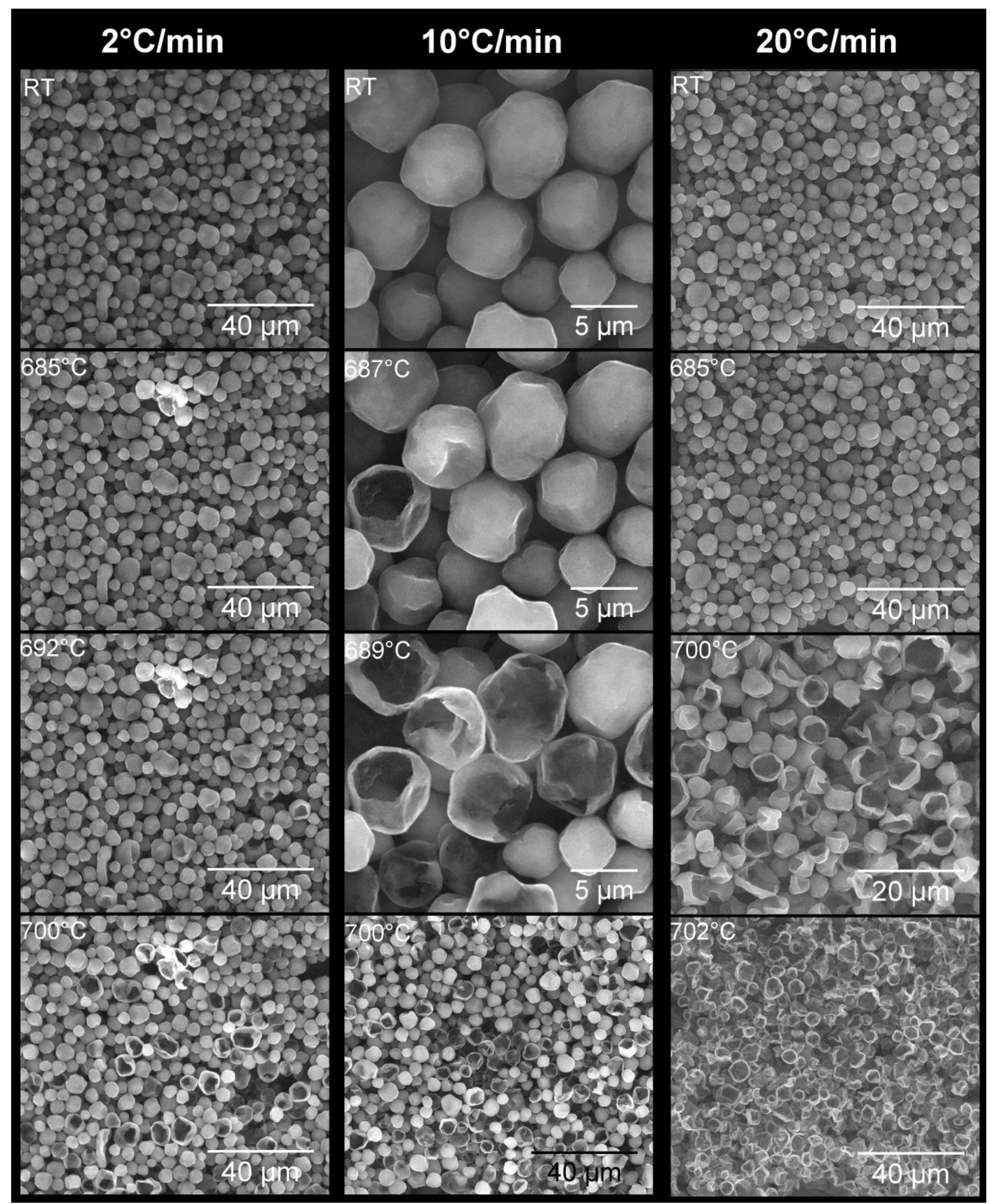

Figure 1. Influence of heating rate on the evolution of the Al microparticles in $\mathrm{He}-4 \% \mathrm{H}_{2}$ annealing atmosphere. 


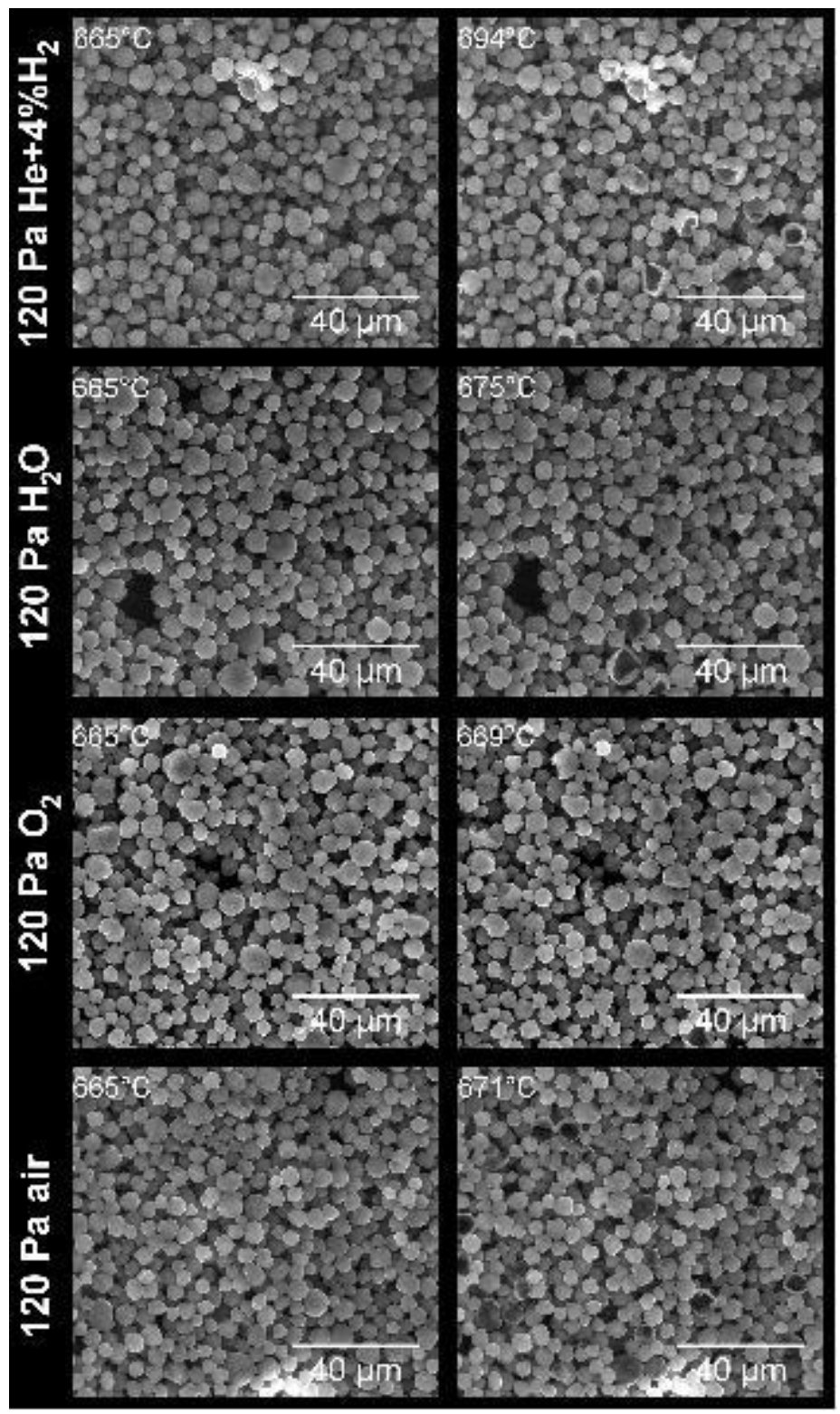

Figure 2. Influence of annealing gas composition on the evolution of the Al microparticles.

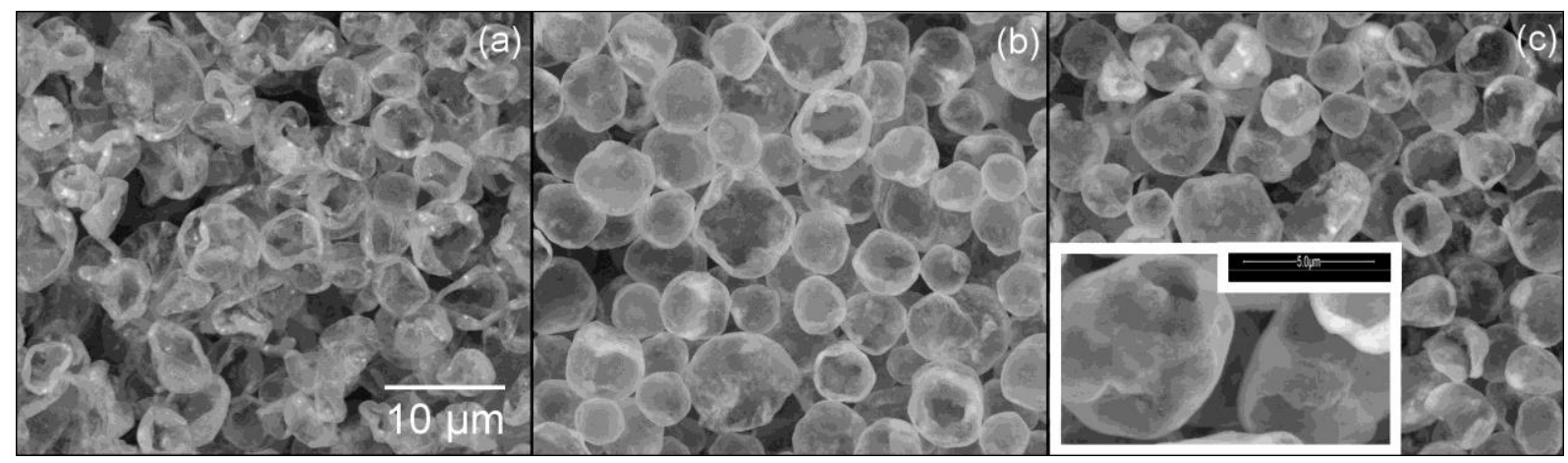

Figure 3.- BSE images after exposure $1150^{\circ} \mathrm{C}$ in (a) $\mathrm{He}-4 \% \mathrm{H}_{2}$, (b) $\mathrm{O}_{2}$ and (c) $\mathrm{H}_{2} \mathrm{O}$. Note the deformation and open spheres in the absence of oxidising species. The inset in (c) allows to appreciate the thickness of the oxide shell covering the particles. 

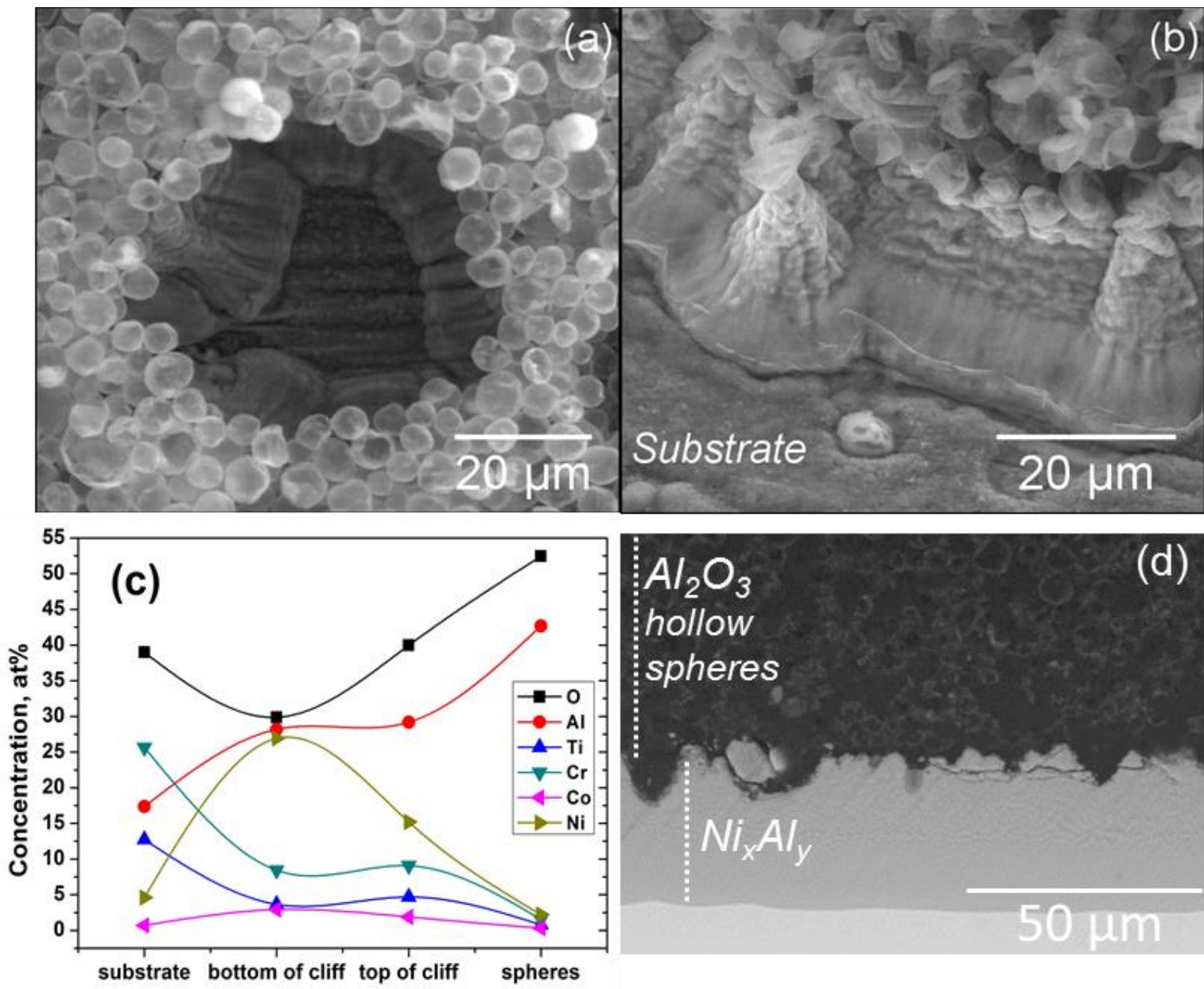

Figure 4.- (a) top view of a pore of the coating after annealing at $1150^{\circ} \mathrm{C}$ in (here for) $\mathrm{He}-4 \% \mathrm{H}_{2}$ and (b) tilted $30^{\circ}$ in another area showing the substrate, the layered structure and the top coat of hollow spheres and (c) the EDS spot analyses of the different areas. Note that the oxygen content was approximately the same ( \pm 10 at\%) regardless of the annealing atmosphere as the analyses were performed in environmental mode. (d) is a cross-section view showing the aluminised substrate $\left(\mathrm{Ni}_{x} \mathrm{Al}\right.$ y intermetallic phase) underneath the top coat of $\mathrm{Al}_{2} \mathrm{O}_{3}$ hollow spheres. 


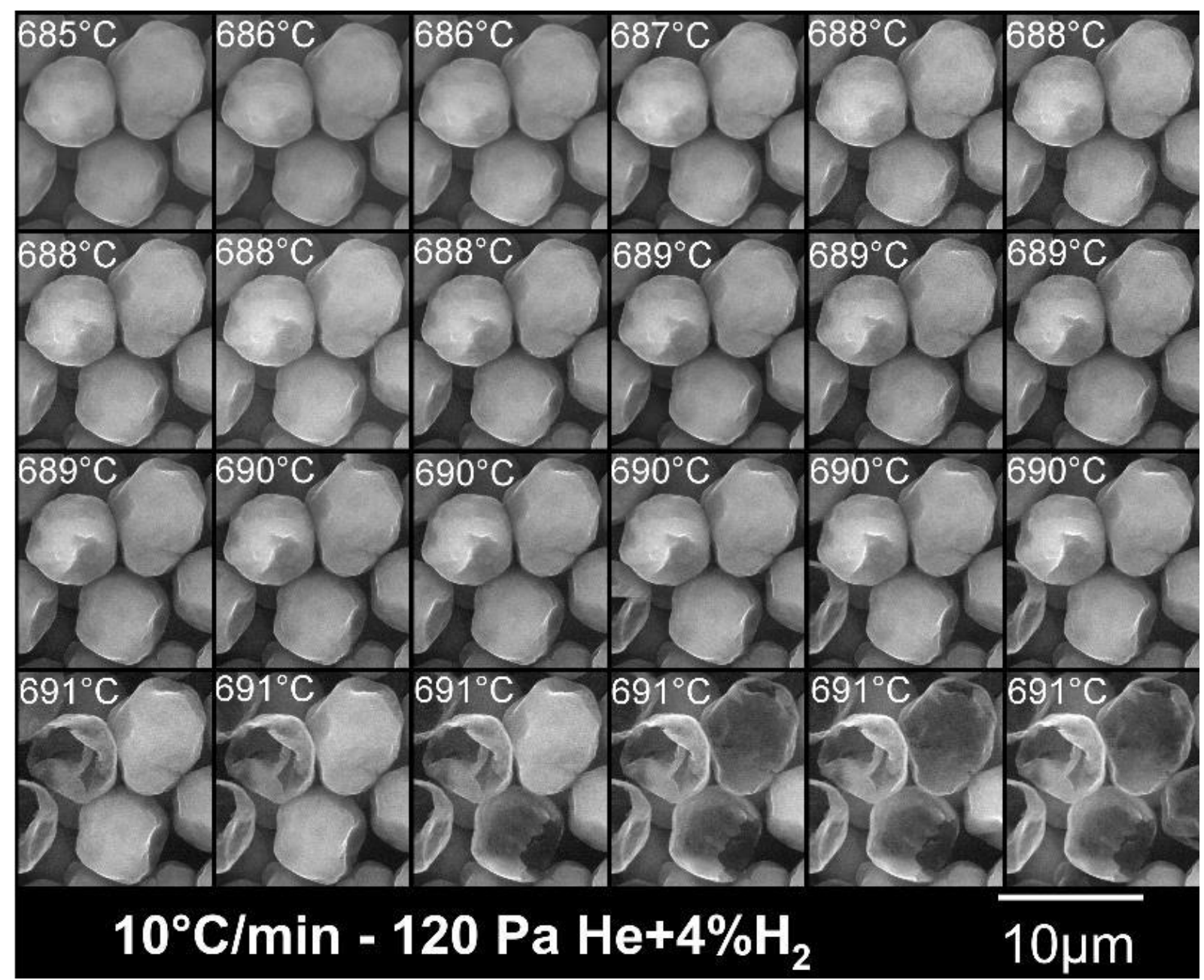

Figure. 5 - Mechanism of formation of individual $\mathrm{Al}_{2} \mathrm{O}_{3}$ hollow spheres. 


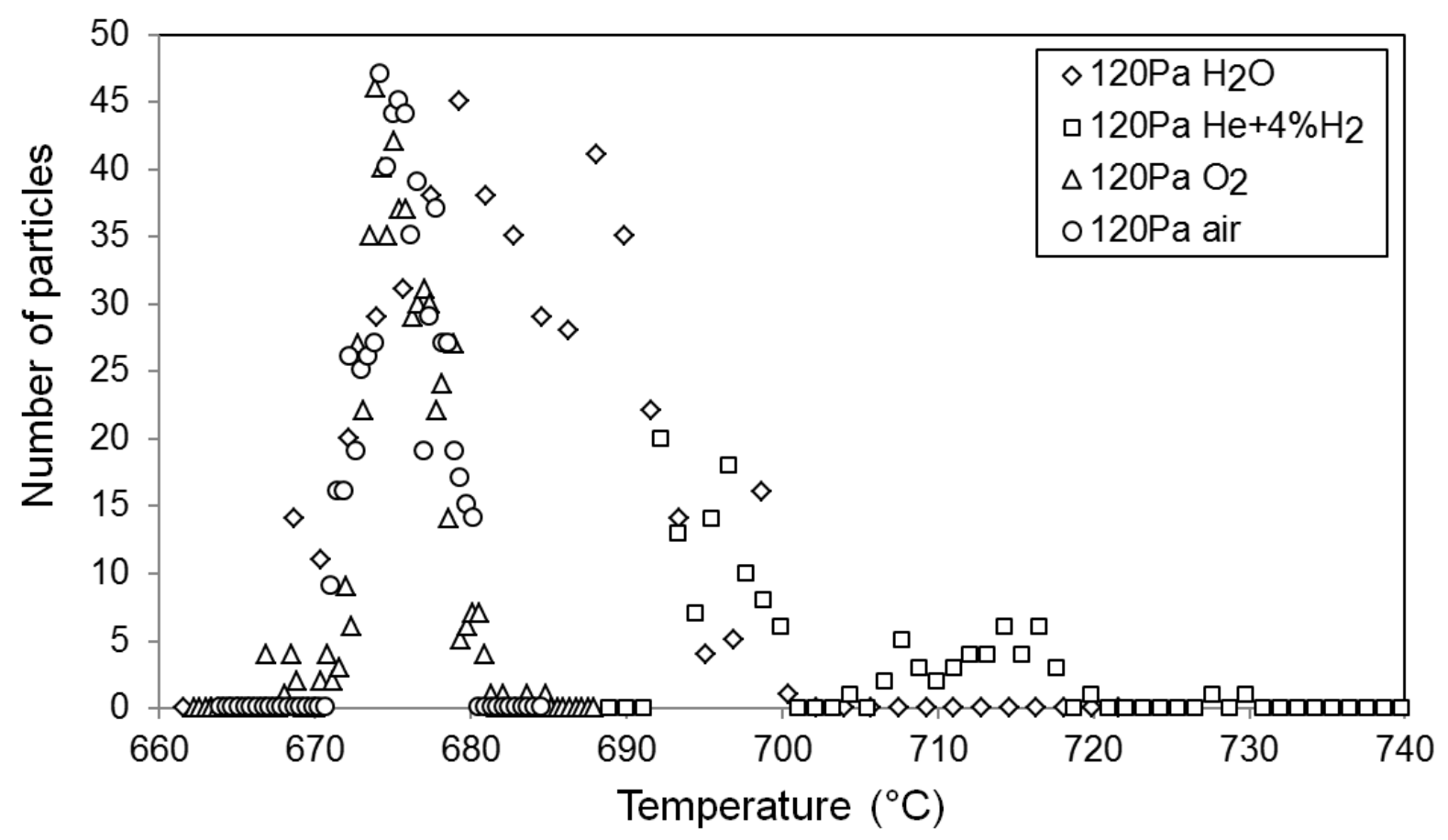

Figure 6.- Statistical distribution of the number of particles that opened in $120 \mathrm{~Pa}$ of $\mathrm{He}-4 \% \mathrm{H}_{2}$, $\mathrm{O}_{2}$, air and $\mathrm{H}_{2} \mathrm{O}$ with respect temperature.

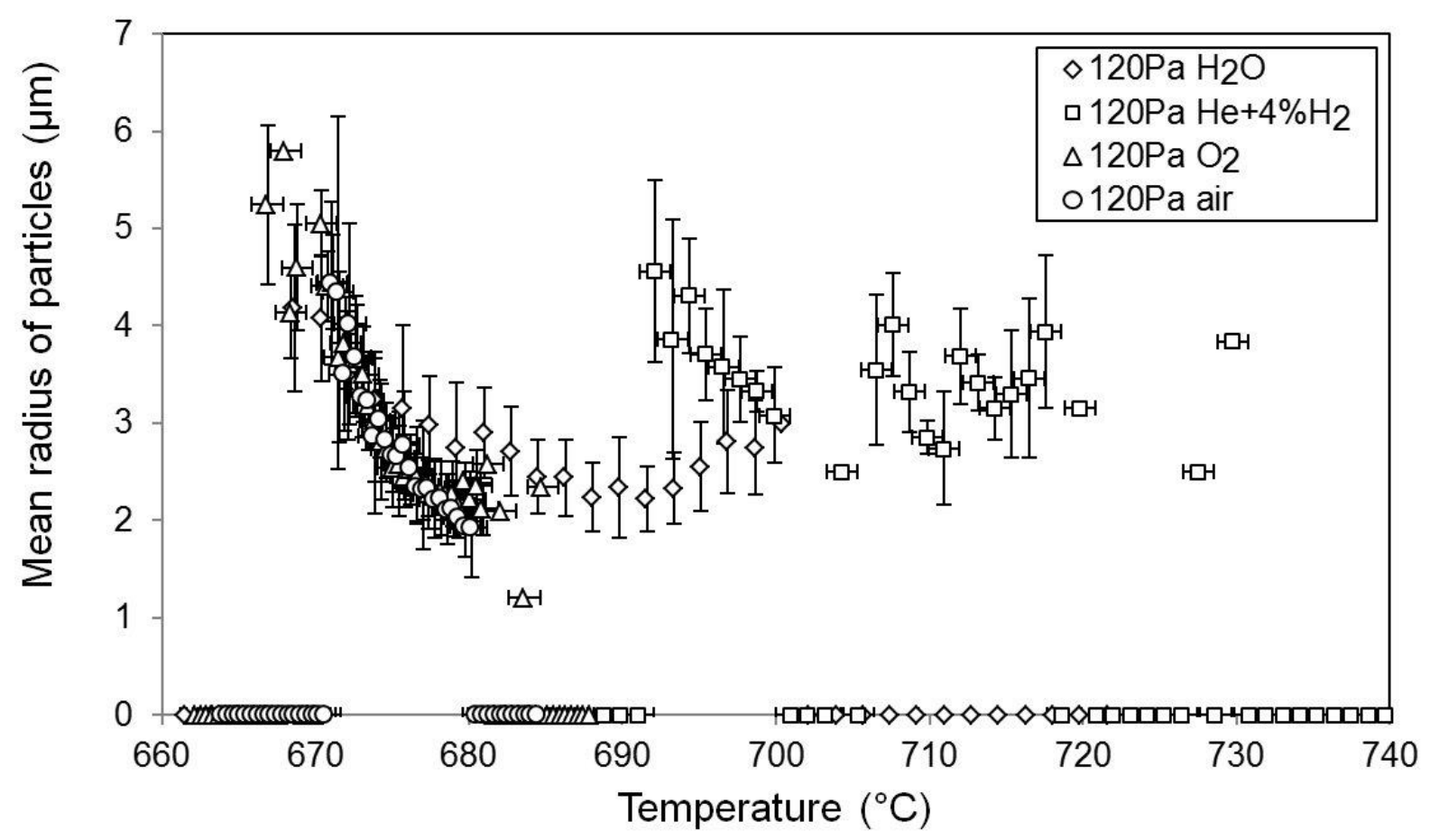

Figure 7.- Mean particle radius opening with respect temperature at $120 \mathrm{~Pa}$ of $\mathrm{He}-4 \% \mathrm{H}_{2}, \mathrm{O}_{2}$, air and $\mathrm{H}_{2} \mathrm{O}$. 


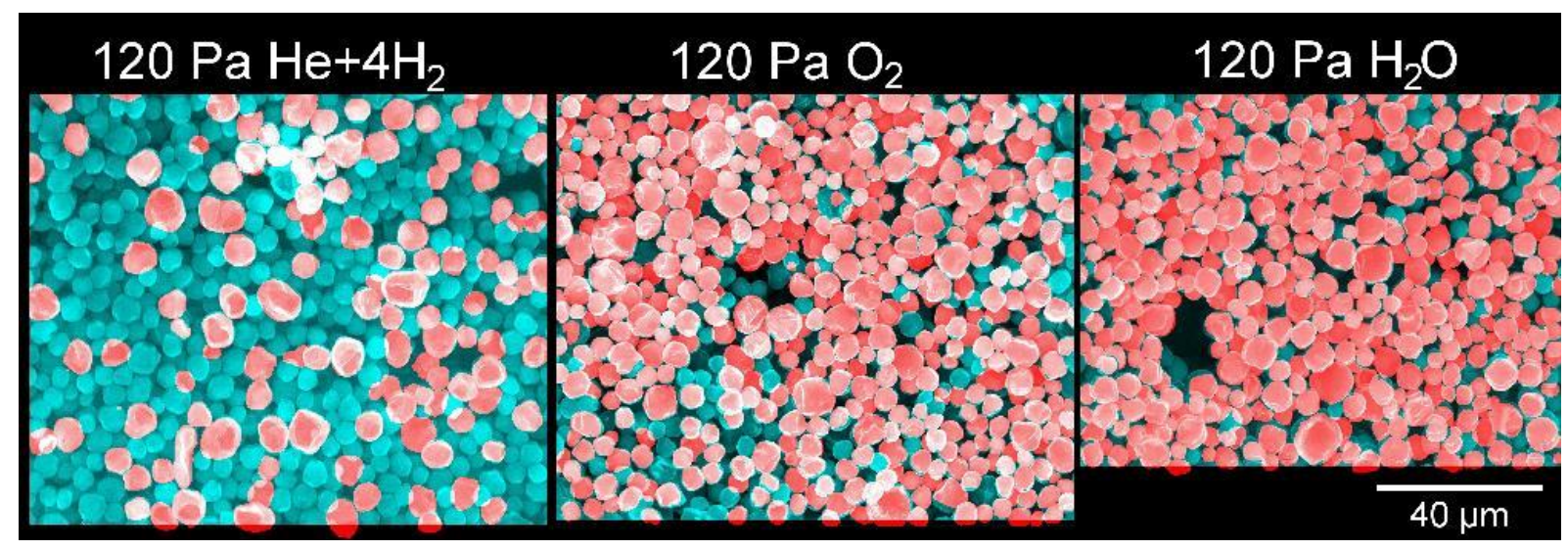

Figure 8. Surface of the samples after heat treatment at $850^{\circ} \mathrm{C}$ showing the formation of hollow alumina spheres and the surface coverage $\left(33.5 \%\right.$ in $\mathrm{He}+4 \mathrm{H}_{2} ; 73.6 \%$ in $\mathrm{O}_{2} ;$ more than $79.2 \%$ in $\mathrm{H}_{2} \mathrm{O}$ ) with a heating rate $5^{\circ} \mathrm{C} \mathrm{min}^{-1}$.

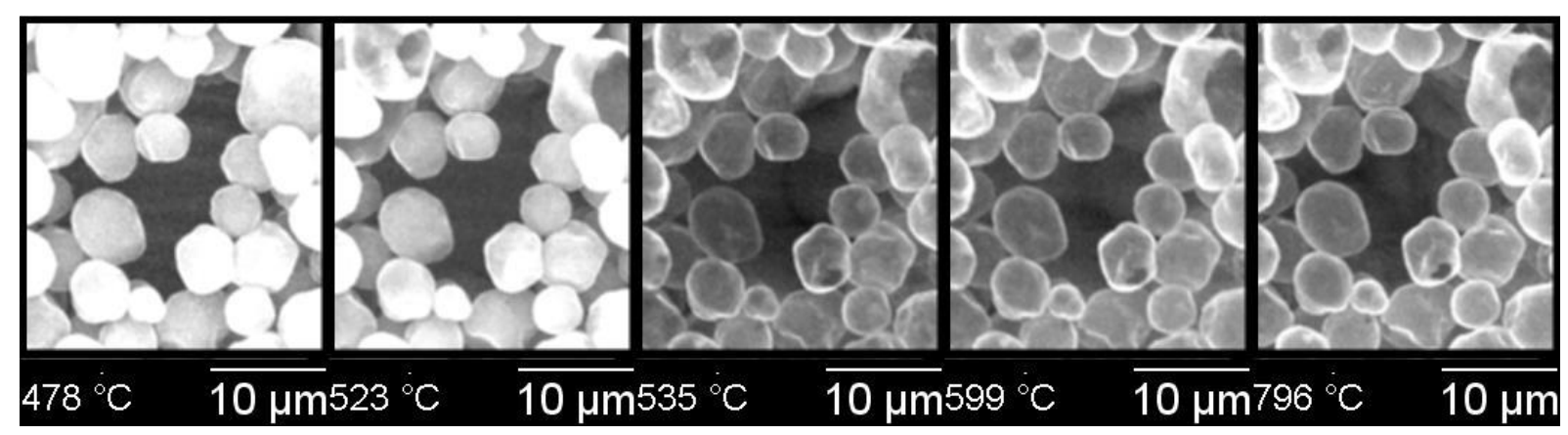

Figure 9 - Aluminisation of the substrate $\left(\right.$ at $\left.5^{\circ} \mathrm{C} \mathrm{min}^{-1}\right)$. Note the coverage of the substrate (centre of the pore) with increasing temperature. 
Supplementary file captions

S1. In situ observation of alumina shell formation in $120 \mathrm{~Pa} \mathrm{He}+4 \% \mathrm{H}_{2}$. Recorded images are shown on the left side of the video and the instantaneous formation of hollow alumina spheres is reported on the right side of the video. The heating rate is $2^{\circ} \mathrm{C} / \mathrm{min}$.

S2. In situ observation of alumina shell formation in $120 \mathrm{~Pa} \mathrm{H}_{2} \mathrm{O}$. Recorded images are shown on the left side of the video and the instantaneous formation of hollow alumina spheres is reported on the right side of the video. The heating rate is $5^{\circ} \mathrm{C} / \mathrm{min}$.

S3. In situ observation of alumina shell formation in $120 \mathrm{~Pa} \mathrm{O}_{2}$. Recorded images are shown on the left side of the video and the instantaneous formation of hollow alumina spheres is reported on the right side of the video. The heating rate is $5^{\circ} \mathrm{C} / \mathrm{min}$.

S4. In situ observation of alumina shell formation in 120Pa air. Recorded images are shown on the left side of the video and the instantaneous formation of hollow alumina spheres is reported on the right side of the video. The heating rate is $5^{\circ} \mathrm{C} / \mathrm{min}$.

S5. Video showing the formation of hollow alumina spheres at high magnification in $120 \mathrm{~Pa} \mathrm{He}+4 \% \mathrm{H}_{2}$. The heating rate is $10^{\circ} \mathrm{C} / \mathrm{min}$.

S6. Video showing the formation of the NiAl diffusion layer at high magnification in $120 \mathrm{~Pa} \mathrm{He}+4 \% \mathrm{H}_{2}$. The heating rate is $2^{\circ} \mathrm{C} / \mathrm{min}$. 